Info Artikel Diterima Februari 2021

Disetujui Maret 2021

Dipublikasikan April 2021

\title{
PEMANFAATAN TEPUNG DAUN KELOR (Moringa oleifera) DALAM \\ RANSUM TERHADAP PRODUKSI NONKARKAS KELINCI NEW ZEALAND WHITE JANTAN
}

\section{UTILIZATION OF MORINGA OLIEFERA LEAF MEAL IN THE RATION ON THE NON CARCASS PRDUCTION OF MALE NEW ZEALAND WHITE RABBIT}

\author{
Rifah Nur Hasanah, Sutaryo*, Endang Purbowati, Retno Adiwinarti \\ Program Studi Peternakan Departemen Peternakan \\ Fakultas Peternakan dan Pertanian Universitas Diponegoro
}

*E-mail: soeta@lecturer.undip.ac.id; sutaryoundip@yahoo.com

\begin{abstract}
The aim of this study was to determine the effect of utilization Moringa oleifera (MO) leaf meal in the ration on the non-carcass production of male New Zealand White rabbits. The treatments were $\mathrm{R} 1$ = ration without MO leaf meal and $\mathrm{R} 2=$ ration with $10 \% \mathrm{MO}$ leaf meal. The results showed that non-carcass production was not significantly different $(\mathrm{P}>0.05)$ between feed treatments. The average weight and percentage of non-carcasses was $1,072.91 \mathrm{~g}$ and $42.87 \%$, head weight and percentage was $238.81 \mathrm{~g}$ and $22.27 \%$, weight and percentage of blood was $66.59 \mathrm{~g}$ and $6.21 \%$, weight and percentage of tails was $13.46 \mathrm{~g}$ and $1.26 \%$, weight and percentage of skin was $250.30 \mathrm{~g}$ and $23.22 \%$, weight and percentage of feet was $62.50 \mathrm{~g}$ and $5.83 \%$ and weight and percentage of net viscera was $234.23 \mathrm{~g}$ and $21,80 \%$. The conclusion of this research is ration without MO meal and without MO gives relatively the same results on the non-carcass production of male New Zealand White rabbits.
\end{abstract}

Key words: Moringa oliefera leaves meal, non-carcass, rabbit.

\begin{abstract}
ABSTRAK
Penelitian ini bertujuan untuk mengetahui pengaruh pemanfaatan tepung daun kelor (Moringa oleifera) dalam ransum terhadap produksi non karkas kelinci New Zealand White (NZW) jantan. Perlakuan yang diberikan yaitu R1 = ransum tanpa tepung daun kelor dan $\mathrm{R} 2=$ ransum dengan kandungan tepung daun kelor $10 \%$. Hasil penelitian menunjukkan bahwa pemanfaatan daun kelor pada ransum kelinci tidak memberikan pengaruh yang signifikan $(\mathrm{P}>0,05)$ pada produksi non karkas kelinci NZW jantan. Rata-rata bobot dan persentase non karkas 1.072,91 g dan 42,87\%, bobot dan persentase kepala 238,81 g dan 22,27\%, bobot dan persentase darah $66,59 \mathrm{~g}$ dan $6,21 \%$, bobot dan persentase ekor 13,46 $\mathrm{g}$ dan 1,26\%, bobot dan persentase kulit 250,30 g dan 23,22\%, bobot dan persentase kaki $62,50 \mathrm{~g}$ dan 5,83\% serta bobot dan persentase viscera nett 234,23 g dan $21,80 \%$. Simpulan penelitian ini adalah bahwa pemberian tepung daun kelor dan
\end{abstract}


tanpa daun kelor memberikan hasil yang relatif sama terhadap produksi non karkas kelinci NZW jantan.

Kata kunci: daun kelor, non karkas, kelinci.

\section{PENDAHULUAN}

Kelinci merupakan salah satu ternak yang dapat menghasilkan daging yang sehat karena mengandung protein yang tinggi namun rendah kolesterol. Menurut Marhaeniyanto dan Susanti (2017) daging kelinci mengandung protein $25 \%$, lemak $4 \%$ dan rendah kolesterol sebesar $1,39 \mathrm{~g} / \mathrm{kg}$ sehinggga aman jika dikonsumsi oleh semua kalangan masyarakat mulai dari anak-anak sampai dewasa (tua). Populasi ternak kelinci di Indonesia menurut Direktorat Jendral Peternakan dan Kesehatan Hewan (2019) dari tahun ke tahun mengalami peningkatan yaitu pada tahun 2015 sebanyak 1.102.964 ekor, tahun 2016 sebanyak 1.201.971 ekor, tahun 2017 sebanyak 1.243.747 ekor, tahun 2018 sebanyak 1.332.026 ekor dan tahun 2019 sebanyak 1.349.894 ekor.

Kelinci tergolong ke dalam ternak pseudoruminansia, hal ini dikarenakan kelinci hanya memiliki satu lapisan lambung, berbeda dengan ruminansia yang memiliki lambung berjumlah lebih dari satu, namun melakukan pencernaan seperti ruminansia di kolon dan sekumnya. Kelinci termasuk ternak herbivora dengan sistem pencernaan monogastrik dan memiliki perkembangan kolon dan sekum untuk mencerna serat kasar. Menurut Marhaeniyanto dan Susanti (2017) selain sebagai ternak pseudo ruminansia kelinci juga memiliki sifat coprophagy yaitu memakan fesesnya kembali untuk mendapatkan kecukupan nutrien. Menurut Noviadi et al. (2017) kelinci tidak bisa mencerna serat kasar secara maksimal, karena memiliki tipe pencernaan monogastrik, sehingga hanya sebagian serat kasar dari pakan nabati yang bisa dicerna, oleh karena itu perlu diberi konsentrat.

Kelinci memiliki potensi untuk dikembangkan di Indonesia, karena memiliki daging yang rendah kolesterol, harga daging stabil, peminat daging kelinci semakin meningkat, bisa dijadikan kontes serta nilai jual kotoran kelinci tergolong mahal. Menurut Lubis (2017) ada 2 jenis kelinci yang populer dikembangkan di Indonesia yaitu kelinci tipe pedaging dan kelinci tipe hias. Tujuan dari pemeliharaan kelinci pedaging yaitu untuk diproduksi dagingnya, sedangkan kelinci hias bertujuan untuk pemenuhan kebutuhan estetik seperti hiburan, hobby dan kontes. Menurut Masanto dan Agus (2010) kelinci pedaging dikembangbiakkan untuk diambil daging, kotoran dan kulitnya karena memiliki nilai jual tinggi sedangkan tujuan pemeliharaan kelinci hias yaitu sebagai hewan kontes karena bentuknya yang unik, imut dan lucu.

Faktor lingkungan berperan sebesar $70 \%$ terhadap keberhasilan produktivitas ternak dan sisanya dipengaruhi oleh faktor keturunan atau genetik (Fathurohman et al., 2018). Aspek terpenting dari faktor lingkungan dalam industri peternakan adalah pakan, hal ini karena 60-70\% keberhasilan peternakan yang disebabkan oleh faktor lingkungan adalah pakan. Pakan yang memiliki kualitas baik akan memberikan efek yang positif terhadap keberlangsungan hidup ternak untuk memenuhi kebutuhan hidup pokok, tumbuh dan berkembangnya jaringan otot serta meningkatkan produktivitas ternak. Seekor ternak jika tidak 
diberikan pakan yang baik sesuai dengan kebutuhannya maka bisa menurunan produktivitasnya. Menurut Marhaeniyanto dan Susanti (2017) karbohirat, protein, lemak, serat, vitamin, mineral dan air merupakan nutrisi yang harus terkandung di dalam pakan untuk memenuhi kebutuhan ternak yang pemberiannya disesuaikan dengan kebutuhannya.

Kelor merupakan tanaman legume yang tergolong ke dalam tanaman tahunan dan berasal dari suku Moringaceae. Tanaman ini bisa menjadi salah satu pakan alternatif untuk ternak, karena memiliki beberapa kelebihan salah satunya adalah mudah tumbuh di iklim tropis seperti di Indonesia. Kelebihan dari tanaman kelor menurut Marhaeniyanto et al. (2015) yaitu tergolong ke dalam jenis bahan pakan lokal yang mudah diperoleh dan bisa ditanam sendiri, memiliki protein kasar sekitar 26-36\% serta memiliki asam amino esensial yang lengkap. Pemanfaatan tepung daun kelor di dalam ransum sebagai pakan sumber protein diharapkan dapat meningkatkan produksi karkas dan non karkas kelinci New Zaeland White (NZW).

Tujuan dilakukannya penelitian ini yaitu mengetahui pengaruh pemanfaatan tepung daun kelor (Moringa oleifera) dalam ransum terhadap produksi non karkas kelinci NZW jantan. Manfaat yang bisa diambil dari hasil penelitian ini adalah dapat memberikan informasi dan pengetahuan terkait pengaruh pemanfaatan tepung daun kelor terhadap produksi non karkas kelinci.

\section{BAHAN DAN METODE \\ Pakan}

Pakan yang diberikan berbentuk pellet yang merupakan campuran dari beberapa bahan pakan yaitu, bekatul padi, jagung, bungkil kedelai, kulit kopi, tepung daun kelor, pollard, bungkil kelapa, molases dan mineral, selain itu kelinci diberikan pakan berupa hijauan yaitu rumput legetan (Synedrella nodiflora).

\section{Ternak}

Materi yang digunakan dalam penelitian meliputi kelinci NZW (Oryctolagus cuniculus) jantan sejumlah 14 ekor dengan umur 65 - 70 hari dan rata-rata bobot badan awal $1381 \pm 0,11 \mathrm{~g}$. Kelinci ditempatkan di kandang baterai atau kandang individu dengan ukuran $60 \times 40 \times 40 \mathrm{~cm}^{3}$ yang alasnya terbuat dari bambu dan dindingnya terbuat dari kawat ram dan diberi perlengkapan berupa tempat minum otomatis dan manual (nipple) serta tempat pakan dari gerabah.

\section{Peralatan}

Alat yang digunakan saat penelitian berlangsung yaitu timbangan digital dengan ketelitian $1 \mathrm{~g}$ dan memiliki kapasitas maksimal $10 \mathrm{~kg}$ yang berfungsi untuk menimbang kelinci, pakan, plastik zip dan sisa pakan, mesin penepung untuk menghaluskan daun kelor serta mesin pelleter untuk mencetak pakan dalam bentuk pellet. Perlengkapan yang dibutuhkan ketika proses pemotongan yaitu timbangan digital dengan ketelitian $0,1 \mathrm{~g}$ dan kapsitas maksimal $1 \mathrm{~kg}$, cutter besar untuk memotong kelinci dan proses pemotongan bagian-bagian tubuh kelinci, ember dan nampan untuk penampungan darah, form pemotongan yang digunakan untuk mencatat data, trash bag untuk alas penguraian viscera, kapas untuk membersihkan darah yang tercecer, plastik zip untuk membungkus karkas 
dan non karkas, kulkas yang digunakan untuk proses pelayuan karkas serta freezer yang digunakan untuk penyimpanan karkas.

\section{Rancangan Percobaan}

Penelitian ini menggunakan Rancangan Acak Lengkap (RAL) menurut Astuti (2007) dengan 2 perlakuan dan 7 ekor kelinci sebagai ulangan, karena kelinci memiliki umur jenis kelamin, bangsa serta bobot badan awal yang seragam. Ransum disusun secara iso protein dan perlakuan yang diterapkan adalah sebagai berikut :

$\mathrm{R} 1=$ ransum tanpa tepung daun kelor

$\mathrm{R} 2=$ ransum dengan tepung daun kelor $10 \%$

\section{Parameter Penelitian}

Parameter yang diamati persentase non karkas dan komponennya (kepala, kulit, kaki, ekor, darah, serta viscera neto. Menurut Kartadisastra, (1997) persentase non karkas dapat dihitung dengan menggunakan rumus sebagai berikut,

Non karkas $(\%)$

Kepala $(\%)$

Darah $(\%)$

Ekor $(\%)$

Kulit $(\%)$

Kaki (\%)

Viscera nett dari non karkas (\%)

$$
\begin{aligned}
& =\frac{\text { bobot non karkas }}{\text { bobot potong }} \times 100 \% \\
& =\frac{\text { bobot kepala }}{\text { bobot non karkas }} \times 100 \%
\end{aligned}
$$$$
=\frac{\text { bobot darah }}{\text { bobot non karkas }} \text { X 100\% }
$$$$
=\frac{\text { bobot ekor }}{\text { bobot non karkas }} \times 100 \%
$$$$
=\frac{\text { bobot kulit }}{\text { bobot non karkas }} \times 100 \%
$$$$
=\frac{\text { bobot kaki }}{\text { bobot non karkas }} \times 100 \%
$$$$
=\frac{\text { bobot visera neto }}{\text { bobot non karkas }} \times 100 \%
$$

\section{Prosedur Penelitian}

Penelitian dibagi menjadi 5 tahap, yaitu tahap persiapan, tahap adaptasi, tahap pendahuluan, tahap perlakuan pakan, dan tahap pemotongan. Tahap persiapan dilakukan selama 4 minggu yang meliputi persiapan kandang, persiapan pakan, persiapan ternak serta persiapan peralatan.

Persiapan kandang dilakukan dengan cara pemasangan kandang baterai, sanitasi kandang, pemasangan tempat pakan dan minum serta pemberian kode di masing-masing kandang baterai. Persiapan pakan dilakukan dengan cara pemilihan bahan pakan, pengadaan bahan pakan, analisis bahan pakan serta penyusunan ransum dan pembuatan pakan pellet. Pembuatan pakan pellet dilakukan dengan cara mempersiapkan bahan penyusun ransum, kemudian dilakukan penimbangan sesuai dengan formulasi yang telah dibuat, pencampuran bahan pakan, kemudian proses pencetakan pellet, penjemuran dan penyimpanan. Persiapan ternak dilakukan dengan cara memesan kelinci sesuai dengan kriteria bangsa NZW bobot badan seragam, umur lepas sapih (65 - 70 hari) dan jenis 
kelamin jantan, kemudian persiapan peralatan dilakukan dengan cara menyiapkan peralatan yang dibutuhkan seperti timbangan analitik, alat tulis dan plastik zip.

Tahap adaptasi, baik adaptasi pakan maupun adaptasi lingkungan kandang berlangsung selama 2 minggu. Adaptasi pakan dilakukan dengan cara memasukkan kelinci ke dalam kandang, kemudian diberikan pakan campuran dari pabrik dan pakan perlakuan secara bertahap sampai kelinci mengkonsumsi pakan perlakuan $100 \%$. Adaptasi lingkungan dilakukan dengan cara pemberian vitamin scott emultion $1 \mathrm{ml} /$ ekor kelici yang bertujuan untuk meningkatkan kekebalan tubuh kelinci serta pemberian obat diapet untuk kelinci yang mencret dengan dosis 2 tablet diapet untuk 1 ekor kelinci.

Tahap selanjutnya yaitu pendahuluan yang berlangsung selama 1 minggu dan diawali dengan pengacakan ternak terhadap perlakuan pakan dan penempatan ternak ke masing-masing kandang yang bertujuan untuk menghilangkan pengaruh pakan sebelumnya. Kemudian di akhir tahap pendahuluan dilakukan penimbangan ternak untuk mengetahui bobot badan awal kelinci.

Tahap selanjutnya yaitu perlakuan yang dilaksanakan 8 minggu kemudian setiap hari kelinci diberi pakan pellet $125 \mathrm{~g}$ sesuai dengan perlakuan dan pemberiannya dilakukan 2 kali sehari yaitu pada pagi hari pukul 07.00 WIB dan sore pukul 16.00 WIB, kemudian di sore harinya kelinci diberi pakan tambahan berupa hijauan yaitu rumput legetan (Synedrella nodiflora) sebanyak $10 \mathrm{~g}$ untuk membantu meningkatkan kekebalan tubuh kelinci karena mengandung sapoin dan polifenol yang dapat mencegah dan meminimalisisr terjadinya kembung/bloat pada ternak. Saponin dapat mengefisienkan produktivitas ternak serta dapat membantu dalam menghambat proses metanogenesis (Wahyuni et al., 2014).

Setiap pagi hari dilakukan penimbangan sisa pakan yang digunakan untuk mengetahui konsumsi pakan harian kelinci. Penimbangan kelinci dilakukan 1 minggu sekali untuk mengetahui pertambahan bobot badan mingguannya. Tahap selanjutnya yaitu pemotongan kelinci yang berlangsung selama 2 hari berturutturut dan setiap harinya dilakukan pemotongan sebanyak 7 ekor kelinci. Kelinci yang dipotong terlebih dahulu adalah kelinci yang memiliki bobot badan paling besar di masing-masing perlakuan. Pemotongan diawali dengan penimbangan ternak kelinci untuk mengetahui bobot badan sebelum dipuasakan, kemudian dilakukan pemuasaan selama 12 jam setelah itu kelinci ditimbang lagi untuk mendapatkan data bobot badan setelah pemuasaan kelinci (bobot potong).

Tahap selanjutnya yaitu dilakukan penyembelihan kelinci secara halal pada bagian leher untuk memutuskan saluran pembuluh darah dengan cara memotong arteri carolis dan vena jugularis, kemudian memotong batang tenggorok dan oesophagus. Tahap selanjutnya yaitu dilakukan penimbangan untuk mengetahui bobot mati kelinci, kemudian dilakukan pemotongan bagian kepala di bagian batas sendi putar tulang atlas, kemudian pemotongan ke empat kaki di bagian persendian antara tarsal dan carpal, kemudian dilakuan pemotongan ekor dan dilakukan pengkulitan, kemudian semua organ dalamnya (viscera) dikeluarkan yang selanjutnya dilakukan penimbangan masing-masing organnya. 


\section{Analisis Data}

Data yang diperoleh dianalisis dengan uji $\mathrm{t}$ untuk membandingkan produksi non karkas menurut Astuti (2007).

\section{HASIL DAN PEMBAHASAN}

Komponen non karkas terdiri dari kepala, darah, ekor, kulit, keempat kaki bagian bawah serta viscera. Hasil penelitian bobot dan persentase komponen non karkas kelinci NZW jantan tidak berbeda nyata $(\mathrm{P}>0,05)$ dan ditampilkan pada Tabel 1.

Berdasarkan Tabel 1 diketahui bahwa kedua perlakuan pakan memberikan hasil yang relatif sama $(\mathrm{P}>0,05)$ terhadap bobot kepala dan kaki dengan rata-rata $238,81 \mathrm{~g}(22,27 \%)$ dan $62,50 \mathrm{~g}(5,83 \%)$. Hal ini diduga karena bobot potong dan non karkas antar perlakuan relatif sama. Menurut Siregar et al. (2014) bobot potong akan berpengaruh terhadap bobot kepala yang termasuk bagian non karkas kelinci. Hasil penelitian Brahmantiyo et al. (2017) bahwa kelinci NZW yang diberi perlakuan protein $17,8 \%$ dan dipotong pada umur 6 bulan menghasilkan bobot kepala 285,26 g dan bobot kaki 97,21 g, lebih tinggi dari penelitian ini yang diberi protein $17 \%$ dan dipotong pada umur 4 bulan. Komponen kepala dan kaki termasuk organ non karkas yang sudah tidak dapat tumbuh dan berkembang lagi setelah kelinci dewasa tubuh. Menurut Tamam (2017) tulang merupakan salah satu organ yang mengalami perkembangan pesat di awal dan apabila perkembangannya sudah maksimal maka akan dikuti oleh daging dan lemak. Atmaja et al. (2017) menyatakan bahwa organ hati, otak dan ginjal, tulang dan paru-paru merupakan organ non karkas yang akan mengalami pertumbuhan dan perkembangan maksimal ketika mencapai dewasa tubuh atau sekitar umur \pm 4 bulan.

Tabel 1. Bobot dan Persentase Komponen Non Karkas

\begin{tabular}{|c|c|c|c|c|}
\hline Parameter & & R1 & $\mathrm{R} 2$ & Rata-rata \\
\hline \multirow{2}{*}{ Kepala } & (g) & 243,50 & 234,13 & 238,81 \\
\hline & $(\%)$ & 21,94 & 22,60 & 22,27 \\
\hline \multirow[t]{2}{*}{ Darah } & (g) & 68,57 & 64,61 & 66,59 \\
\hline & $(\%)$ & 6,18 & 6,24 & 6,21 \\
\hline \multirow[t]{2}{*}{ Ekor (g) } & (g) & 14,69 & 12,22 & 13,46 \\
\hline & $(\%)$ & 1,33 & 1,18 & 1,26 \\
\hline \multirow[t]{2}{*}{ Kulit (g) } & (g) & 257,74 & 242,86 & 250,30 \\
\hline & $(\%)$ & 23,22 & 23,44 & 23,22 \\
\hline \multirow[t]{2}{*}{ Kaki (g) } & (g) & 64,82 & 60,18 & 62,50 \\
\hline & $(\%)$ & 5,84 & 5,81 & 5,83 \\
\hline \multirow[t]{2}{*}{ Viscera nett } & (g) & 252,19 & 216,26 & 234,23 \\
\hline & $(\%)$ & 22,72 & 20,87 & 21,80 \\
\hline
\end{tabular}

Keterangan : Hasil analisis statistik menunjukkan tidak berbeda nyata $(\mathrm{P}>0,05)$.

Bobot kulit kedua perlakuan memberikan hasil yang relatif sama $(\mathrm{P}>0,05)$ dengan rata - rata $250,30 \mathrm{~g}(23,22 \%)$ yang berarti penambahan tepung daun kelor pada taraf $10 \%$ tidak memberikan pengaruh terhadap bobot kulit. Hal ini diduga 
karena bobot potong dan non karkas kedua perlakuan juga relatif sama. Bobot potong dan bobot kulit berbanding lurus, apabila semakin tinggi bobot potong berati ternak semakin besar maka bobot kulitnya akan semakin luas. Menurut Abdullah et al. (2017), bobot kulit dipengaruhi oleh bobot potong ternak, sehingga apabila bobot potong, sama maka bobot kulit juga relatif sama. Hasil penelitian Brahmantiyo et al. (2017) pada kelinci NZW yang diberi perlakuan protein 17,8\% dan dipotong pada umur 6 bulan menghasilkan bobot kulit 369,66 g lebih tinggi dari penelitian ini yang diberi protein $17 \%$ dan dipotong pada umur 4 bulan dengan rata-rata kulit 250,30 g.

Bobot darah kelinci pada kedua perlakuan memberikan hasil yang relatif sama $(\mathrm{P}>0,05)$ dengan rata - rata 66,59 g $(6,21 \%)$. Hal ini diduga karena bobot potong dan bobot non karkas ternak kelinci relatif sama. Menurut Dagong et al. (2012), bobot potong ternak yang tidak berbeda nyata akan berpengaruh terhadap bobot darah yang merupakan komponen non karkas. Hasil penelitian Brahmantiyo et al. (2017) pada kelinci NZW dengan bobot potong 3.133,33 g menghasilkan bobot darah 106,21 g lebih tinggi dari penelitian ini.

Bobot ekor dan viscera kelinci pada kedua perlakuan tidak berbeda nyata ( $\mathrm{P}>0,05)$ dengan rata-rata 13,46 g (1,26\%) dan 234,23 g (21,80\%). Hal ini diduga karena kedua perlakuan pakan pellet yang digunakan memiliki kandungan SK relatif sama (Tabel 4), sehingga bobot viscera relatif sama. Menurut Atmaja et al. (2017) kandungan serat kasar pada pakan akan mempengaruhi waktu cerna dari viscera, semakin rendah serat kasar maka semakin cepat viscera dalam mencerna pakan dan akan memperkecil bobot viscera begitu pula sebaliknya. Menurut Soeparno (2005) bobot komponen non karkas dipengaruhi oleh pakan, namun pengaruhnya variatif. Hasil penelitian Brahmantiyo et al. (2017) pada kelinci NZW yang diberi perlakuan protein 17,8\% dan dipotong pada umur 6 bulan menghasilkan bobot viscera $458,54 \mathrm{~g}$ lebih tinggi dari penelitian ini yang diberi protein $17 \%$ dan dipotong pada umur 4 bulan.

\section{KESIMPULAN DAN SARAN}

Pemanfaatan daun kelor pada ransum memberikan hasil yang relatif sama terhadap produksi non karkas kelinci NZW jantan. Tepung daun kelor dapat dimanfaatkan sebagai bahan penyusun ransum kelinci sebanyak $10 \%$.

\section{DAFTAR PUSTAKA}

Abdullah, Made, Dwi., Nur, Hanafi., dan Anggraeni, Anggraeni (2017). "Karakteristik Non Karkas Kelinci Yang Diberi Pakan Tambahan Tepung Daun Sirsak Dan Zeolit” Jurnal Pertanian Vol 8. No.1 2017. Hal 51-57.

Astuti, M. 2007. Pengantar Ilmu Statistik untuk Peternakan dan Kesehatan Hewan. Binasti Publisher, Bogor.

Atmaja, C. G. R., Sriyani, N. L. P., dan Nuriyasa, I. M.. (2017). "Pengaruh Pemanfaatan Limbah Wine Sebagai Pakan Terhadap Non Karkas Internal 
Kelinci Lokal (Lepus Nigricollis)" Jurnal Peternakan Tropika Vol 5. No.2 2017. Hal 396-406.

Brahmantiyo, B., Nuraini H., dan Rahmadiansyah, D. 2017. Produktivitas Karkas Kelinci Hyla, Hycole dan New Zealand White. Prosiding Seminar Nasional Teknologi Peternakan dan Veteriner. Hal 616-626.

Dagong, Muhammad, Ihsan, Andi., Herman, R., Sumarti, C., Noor, R.R., dan Yamin, M. (2012). "Karakteristik Karkas Dan Sifat Daging Domba Ekor Tipis (DET) Berdasarkan Variasi Genotip Gen Kalpastatin (CAST) (Lokal intron 5-ekson 6)" Jurnal Ilmu Ternak dan Veteriner Vol 17. No.1 2012. Hal 13-24.

Direktorat Jendral Peternakan dan Kesehatan Hewan. 2019. Statistik Peternakan dan Kesehatan Hewan. Direktorat Jendral Peternakan dan Kesehatan Hewan Kementerian Pertanian RI, Jakarta.

Fathurohman, Fendi., Rita, Purwasih., dan Ridwan, Baharta (2018). "Peningkatan Produktivitas Ternak Dan Manajemen Peternakan Di Sentra Peternakan Rakyat (SPR) Cinagaraboga Subang" Jurnal Pengabdian kepada Masyarakat Vol 2. No.3 2018. Hal 139-142.

Kartadisastra, H. R. 1997. Ternak Kelinci. Kanisius, Yogyakarta.

Lubis, Adi, Prijuna (2017). "Penentuan Jenis Kelinci Pedaging Terbaik Dengan Menggunakan Metode Fuzzy Multi Criteria Decision Making” Jurnal Teknologi dan Sistem Informasi Vol 4. No.1 2017. Hal 57-64.

Marhaeniyanto, Eko dan Sri, Susmasanti (2017). "Penggunaan Konsentrat Hijau Untuk Meningkatkan Produksi Ternak Kelinci New Zealand White” Jurnal Ilmu - Ilmu Peternakan Vol 27. No.1 2017. Hal 28-39.

Marhaeniyanto, Eko., Sugeng, Rusmiwari dan Sri, Susanti (2015). "Pemanfaatan Daun Kelor Untuk Meningkatkan Produksi Ternak Kelinci New Zealand White” Jurnal Buana Sains Vol 15. No.2 2015. Hal 119-126.

Masanto, R. dan Ali, A. 2010. Beternak Kelinci Potong. Penebar Swadaya, Jakarta Timur.

Noviadi, Riko., Anjar, Sofiana dan Imelda, Panjaitan (2017). "Pengaruh Penggunaan Tepung Jagung Dalam Pembuatan Silase Limbah Daun Singkong Terhadap Perubahan Nutrisi, Kecernaan Bahan Kering, Protein Kasar Dan Serat Kasar Pada Kelinci Lokal" Jurnal Penelitian Pertanian Terapan Vol 12. No.1 2017. Hal 6-12. 
Siregar, G. A. W., H. Nuraini dan B. Brahmantiyo (2014). "Pertumbuhan dan Produksi Karkas Kelinci Rex Pada Umur Potong Yang Berbeda" Jurnal Ilmu Produksi dan Teknologi Hasil Peternakan Vol 2. No.1 2014. Hal 196-200.

Soeparno. 2005. Ilmu dan Teknologi Daging. Gadjah Mada University Press, Yogyakarta.

Tamam, Khoirul, 2017. Persentase Komponen Karkas Kelinci Peranakan New Zaeland White yang Dipelihara pada Suhu Lingkungan yang Berbeda. Skripsi. Universitas Brawijaya.

Wahyuni, I. M. D., Muktiani, A., dan Christianto, M. (2014). "Penentuan Dosis Tanin Dan Saponin Untuk Defaunasi Dan Peningkatan Fermentabilitas Pakan" Jurnal Institut Teknologi Padang Vol 3. No.3 2014. Hal 13-140. 